\title{
Antigen-Presenting Cells and their Fc $\gamma$ and Toll-Like Receptors: Leading Suspects in Autoimmunity
}

\author{
Kim C.M. Santegoets, Lenny van Bon, Mark H. Wenink* and Wim B. van den Berg
}

Radboud University Nijmegen Medical Centre, Department of Rheumatology, The Netherlands

\begin{abstract}
Antigen-presenting cells (APCs) play an important role in the development of autoimmune diseases. These cells recognize pathogen associated molecular patterns but also endogenously produced ligands through toll-like receptors (TLRs). Aberrant activation of these receptors and the following intracellular signaling pathways can induce the deleterious production of pro-inflammatory cytokines. In genetically predisposed individuals this might lead to a breach in tolerance and eventually autoimmunity. IgG and IgG immune complexes (ICs), which are abundantly present in autoimmune diseases like systemic lupus erythematosus (SLE), rheumatoid arthritis (RA) and systemic sclerosis (SSc) are recognized by APCs via Fc gamma receptors ( $F c \gamma R s)$ and can also modulate their activation state. Upon their uptake specific antigens present in ICs are capable of stimulating APCs via their intracellular TLRs, increasing their capability to induce (autoreactive) $\mathrm{T}$ and $\mathrm{B}$ cell responses. This underscores their likely role in the generation and maintenance of autoimmunity. By focusing on three autoimmune diseases, SLE, RA and SSc, we will illustrate the importance of TLRs and FcyRs in the pathogenesis of autoimmune diseases.
\end{abstract}

Keywords: Toll Like Receptors, Fc gamma receptors, Antigen-presenting cells, Systemic lupus erythematosus, Rheumatoid arthritis, Systemic sclerosis.

\section{INTRODUCTION}

Most systemic autoimmune disorders, such as systemic lupus erythematosus (SLE), rheumatoid arthritis (RA) and systemic sclerosis (SSc) are diagnosed by the use of a set of defined classification criteria mirroring their phenotypic heterogeneity [1-3]. Variation in the underlying etiologic factors, such as environmental factors and the genetic background, seems to underlie this clinical complexity and phenotypic variability. A crucial etiologic factor seems to be the presence of specific antibodies aimed at endogenous ligands. Antibodies of the IgG type and IgG containing immune complexes (IC) are recognized by $\mathrm{Fc}$ gamma receptors (Fc $\gamma \mathrm{Rs}$ ). These receptors are expressed by many kinds of immune cells including antigen-presenting cells (APCs) such as myeloid and plasmacytoid dendritic cells (DC), monocytes and macrophages. The family of Fc $\gamma$ Rs consists of the

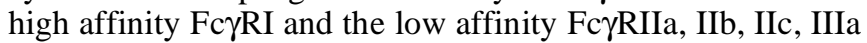
and IIIb. Fc $\gamma$ RIIb is the only Fc $\gamma \mathrm{R}$ with an immunoreceptor tyrosine-based inhibition motif (ITIM) instead of an activation motif (ITAM). IC binding to activating Fc $\gamma$ Rs can induce phagocytosis, antigen presentation, pro-inflammatory cytokine production and antibody-dependent cellular cytotoxicity. The simultaneous activation of the inhibitory Fc $\gamma$ RIIb inhibits these processes and can prevent the proinflammatory actions caused by the activating receptors [4]. The resulting immune response upon the binding of IC thus depends on the balance between the activating and inhibitory Fc $\gamma$ Rs. Activation of Fc $\gamma$ RIIa on monocyte-derived DCs results in DC maturation, increased stimulation of allogeneic $\mathrm{T}$

*Address correspondence to this author at the Radboud University Nijmegen Medical Centre, Department of Rheumatology, The Netherlands; Tel: +31243540403; Fax: +31243610516; E-mail: m.wenink@ reuma.umcn.nl cells, and enhanced secretion of inflammatory cytokines,

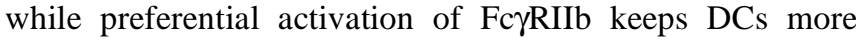
immature, decreases the stimulation of allogeneic $\mathrm{T}$ cells and favors the development of Th2 responses even in the presence of a strong stimulus like lipopolysaccharide $[4,5]$.

It is widely recognized that a loss of immune tolerance to self components due to aberrant $\mathrm{B}$ and $\mathrm{T}$ cell reactivity is the shared basis of complex immune diseases such as SLE, RA and SSc. Type I interferons (IFNs) appear to play a crucial role in the breakdown of self tolerance. The finding that approximately $20 \%$ of patients treated with IFNs for various disorders develop an autoimmune disease underpins this notion [6]. IFNs are prototypically released by APCs, especially plasmacytoid DC (pDC), upon the activation of nucleic acid sensing TLRs. TLRs are pattern recognition receptors capable of recognizing both endogenous molecules released upon cell stress and a wide range of conserved constituents from pathogens [7-9]. Four intracellular TLRs capable of sensing nucleic acids are found in APCs. TLR3 is activated by double stranded RNA (dsRNA), TLR7 and TLR8 by single stranded RNA (ssRNA) and TLR9 by unmethylated CpG DNA. Another TLR known for its capability to induce the release of IFNs is TLR4. TLR4 is expressed extracellular and recognizes lipopolysaccharides (LPS) from bacteria and a wide range of endogenous ligands [10]. An important part of its intracellular signaling cascade is shared with TLR3 explaining its capability of triggering IFN production. TLRs are highly suspected as conductors of autoimmunity [11]. The activation of multiple TLRs leads to the release of copious amounts of pro-inflammatory cytokines creating a volatile situation. In genetically predisposed individuals this might eventually lead to a breach in tolerance culminating in autoimmune disease [12]. The intracellular localization of the nucleic acid sensing TLRs prevents aber- 
rant activation of APCs by endogenous nucleic acids. In many autoimmune diseases however antibodies have been found aimed at nucleic acids or proteins bound to these, enabling endocytosis of these ICs resulting in TLR activation by normally harmless components of self $[13,14]$. This review focuses on FcyR and TLR and their interplay in three prototypical autoimmune diseases, SLE, RA and SSc characterized by autoantibody production and likely mediated by an aberrant activation of TLR expressing APC.

\section{SYSTEMIC LUPUS ERYTHEMATOSUS}

As a hallmark autoimmune disease SLE is a very heterogeneous disease. Individual patients vary in terms of the presence of specific auto-antibodies and the involvement of skin, kidneys, joints, the nervous system and other organs. The disease primarily affects women with a ratio of 9:1 compared to males [15]. Excess formation of ICs due to the production of auto-antibodies causing inflammation and subsequent tissue damage seems to be the main immunological event in SLE. Highly specific antibodies for SLE are those aimed at dsDNA and the Sm proteins (a protein complex that binds small nuclear RNAs). Anti-dsDNA antibodies reflect disease activity in SLE, especially the activity of lupus nephritis [16]. Deposited ICs will induce inflammation by activating FcyR-bearing immune cells such as monocytes, macrophages and plasmacytoid and myeloid DCs.

Since the genetic contribution to SLE is thought to be relatively large [17], it seemed likely that a genetic signature would be identified in SLE patients increasing their risk for the development of auto-antibodies and/or an increased reaction toward these. A fitting association has been found between genes within the human leukocyte antigen (HLA) region on the short arm of chromosome 6 (6q21.3), especially in the major histocompatibility complex HLA-DRB1 and DQB1 loci. Polymorphisms of these determine the fitting of certain epitopes and thus their presentation by APCs to T cells. Therefore these polymorphisms determine the production of specific auto-antibodies against nuclear antigens and the risk of developing SLE [18, 19]. Linked to the aberrant tissue deposition of ICs in SLE, preliminary evidence associates variants of Fc $\gamma$ RIIa and IIIa with the development of SLE [20, 21]. These variants have been found to be less effective than their more frequent counterparts in binding ICs, implicating accumulation of ICs in specific tissues as an etiologic event in SLE. Another well-documented risk factor for SLE lies in the interferon regulatory factor 5 (IRF5) gene. The variants associated with an increased risk to SLE confer an augmented function of IRF5 by increasing its expression [22-24]. IRF5 is tightly involved in the signaling pathway utilized by TLRs activating the transcription of type I IFN and related proteins in APCs [25]. Since TLR7 and TLR8 recognize ssRNA and TLR9 recognizes unmethylated CpG dinucleotide containing single stranded as well as double stranded DNA, these receptors are thought to be heavily involved in the pathogenesis of SLE [26]. Single nucleotide polymorphisms (SNPs) in STAT4, increasing its expression, were recently found by Sigurdsson et al. [27] to be associated with SLE. The presence of these SNPs correlated with the production of antibodies against dsDNA. STAT4 is activated by the ligation of the IFN $\alpha$ receptor and is subsequently translocated to the nucleus, in mature DCs this induces the transcription of various factors resulting in en- hanced $\mathrm{T}$ cell activation [28]. In addition STAT4 transmits signals from the receptors of IL-12p70 and IL-23 and is crucial for the development of the Th1 lineage in humans [29]. Interestingly, IRF5 and STAT4 are, in addition to SLE, selectively associated with an increased risk for other autoimmune diseases with an interferon signature such as RA and SSc, implicating common etiologic pathways for the breaching of tolerance.

Keeping these genetic predispositions in mind it is intriguing to see that the involvement of APCs and their antigen uptake receptors in the pathogenesis of SLE is strongly supported by in vivo and in vitro human data. Raised serum levels of IFN $\alpha$ have been observed in SLE patients and correlated with disease severity [30]. In addition peripheral blood cells of SLE patients demonstrated an increased transcription level of type I IFN regulated genes, probably because of a continuous production of IFN $\alpha$ [31]. A crucial causative role in the induction of this IFN profile might be the presence of RNA or DNA containing ICs. The common auto-antibodies in SLE like anti-dsDNA, anti-Sm proteins, anti-Ro proteins and anti-histone antibodies bind to either dsDNA or proteins complexed with RNA or DNA. These ICs are taken up via Fc $\gamma$ Rs by APCs and by B cells via the B cell antigen receptor [12]. When these ICs reach the endosome they subsequently trigger the intracellular TLR7, TLR8 or TLR9. This leads to the production of proinflammatory cytokines, such as type I IFNs, the up regulation of IFN regulated genes, the maturation of APCs and the presentation of self peptides to autoreactive T cells [32-34]. These autoreactive T cells in turn can help B cells in the production of auto-antibodies. In itself, the direct activation by nucleic acid-containing IC of B cells additionally promotes auto-antibody production [35]. APCs of special interest in SLE are the plasmacytoid DCs. They were demonstrated to be the main producers of type I IFN upon stimulation with dsDNA or Sm containing ICs. These interferogenic ICs are taken up by plasmacytoid DC via Fc $\gamma$ RIIa, are translocated to the endosome and then stimulate the relevant TLR resulting in a massive release of IFN $\alpha[36,37]$. However, since monocytes, macrophages and myeloid DCs express high levels of Fc $\gamma$ Rs and respond vigorously to stimulation with TLR7/8 ligands, nucleic acid containing ICs might also activate these cells to produce pro-inflammatory cytokines. This was previously demonstrated by Boulé et al. using murine bone-marrow DCs which produced TNF $\alpha$ and BAFF upon the stimulation with chromatin IC [32]. Myeloid DCs, upon the activation with TLR7/8 ligands are able to secrete high levels of IL-12p70 and induce the proliferation of Th1 cells, especially in combination with IFN $\alpha$, IFN $\gamma$ or TLR4 ligands $[10,38,39]$. IL-12p70 is the major cytokine in inducing Th1 responses and thus the production of IFN $\gamma$. Blood IL-12p70 and IFN $\gamma$ are elevated in SLE patients and IL-12p70 levels correlate with the SLE disease activity index (SLEDAI) in SLE patients with renal involvement [40, 41]. Correspondingly, the ratio of IFN $\gamma / \mathrm{IL}-4$-producing $\mathrm{CD}^{+}{ }^{+} \mathrm{T}$ cells correlates with the SLEDAI and was significantly higher among patients with lupus nephritis [42]. In addition, IFN $\gamma$ was demonstrated to contribute heavily to nephritis in murine lupus [43]. Nucleic acid-containing ICs may thus start a vicious circle by inducing IFN $\alpha$ from plasmacytoid DCs. In this conceptual framework the released IFN $\alpha$ then primes monocytes and myeloid DCs for TLR7/8 activation by nu- 
cleic acid containing ICs resulting in a synergistic release of IL-12p70. The high levels of IL-12p70 favor the presence of Th1 cells and thus the release of IFN $\gamma$. IFN $\gamma$ in itself primes myeloid lineage cells for the internalization of ICs, the release of IL-12p70 and the presentation of self peptides to autoreactive $\mathrm{T}$ cells enabling them to help $\mathrm{B}$ cells produce antibodies against nucleic acids or proteins bound to these. An observation supportive of this hypothesis was that in SLE, monocyte-derived and myeloid DCs are in a preactivated state promoting DC maturation, pro-inflammatory cytokine release and T cell proliferation [44]. Interestingly, as described above, genes involved in the production of type I IFN and IL-12p70 (IRF5) and its signal transduction in APCs and T cells (STAT4) are heavily implicated in the susceptibility for SLE and might thus contribute to this selfsustaining menacing loop [22-24, 27]. An additional mechanism which might support this vicious circle is the myeloid DC-inducing capacity of SLE serum, mediated through the effect of IFN $\alpha$ on monocytes [45]. The promotion of the differentiation of B cells into plasmablasts and antibodysecreting plasma cells by pDCs activated with SLE ICs seems to be another contributing factor [46]. Of interest, crossing of mice lacking the inhibitory FcyRIIb to the Ylinked autoimmune accelerator (Yaa) locus, which harbors a duplication in the TLR7 gene, markedly enhanced autoimmunity [47], stressing the importance of Fc $\gamma R$ and TLR cooperation in the maintenance of tolerance and the induction of autoimmunity.

The involvement in the pathogenesis of SLE of the type I IFN system consisting of nucleic acid containing ICs and TLRs has been subject of intense investigation during the past years in animal models of SLE. A large body of supportive data has emerged from these studies. The importance of signaling through the IFN $\alpha$ receptor was apparent from experimental murine lupus models in which IFN $\alpha$ receptor knock-out mice had a markedly reduced SLE disease [48]. The essential role played by TLR7 in the pathogenesis of SLE was emphasized by studies demonstrating that mice lacking this receptor do not produce anti-Sm antibodies and have an ameliorated clinical disease [49]. The blockade of TLR7 with synthetic oligodeoxynucleotides in MRL(lpr/lpr) mice also reduced the levels of anti-Sm and anti-dsDNA antibodies and ameliorated lupus nephritis [50, 51]. In addition, over expression of TLR7 accelerated systemic autoimmunity in murine lupus [52]. The role for TLR9 was less clear, whereas triggering of TLR9 with CpG oligonucleotides in MRL(lpr/lpr) mice induced nephritis [53]. Absence of this receptor accelerated clinical disease in MRL(lpr/lpr) mice although it did prevent the occurrence of anti-dsDNA antibodies [54].

These emerging data suggestive of a causal relationship between auto-antibodies, an over-activated type I IFN system and SLE indicate that these could be therapeutic targets. Supportive are data from two effective therapeutic agents in SLE, hydroxychloroquine and glucocorticoids. These drugs prevent activation of the intracellular TLRs, inhibit IFN $\alpha$ production by $\mathrm{pDCs}$ and suppress the IFN signature $[55,56]$. Interestingly, preliminary results from a phase I clinical trial with a neutralizing antibody against IFN $\alpha$ were very encouraging with a dose-dependent inhibition of type I IFNinducible genes as well as a prominent reduction in clinical disease activity [57]. In another clinical trial (phase III) an agent (Abetimus sodium) selectively aimed at removing antidsDNA antibodies from the blood was used. Although not all clinical parameters improved notably a significant reduction in SLEDAI and proteinuria was observed corresponding to the reduction of circulating anti-dsDNA antibodies, underscoring the pathological role of these antibodies. A possible explanation for the limited clinical effect of this agent might be that the remaining RNA-containing IC induced sufficient amounts of IFN $\alpha$ to maintain the chronic inflammatory process [58].

\section{RHEUMATOID ARTHRITIS}

RA is a systemic autoimmune disease characterized by chronic synovial inflammation and subsequent damage to cartilage and bone, leading to severe disabilities. Most RA patients have auto-antibodies against the $\mathrm{Fc}$ portion of IgG molecules (Rheumatoid Factor) and citrullinated proteins. The most frequent proteins against which anti-citrullinated protein/peptide antibodies (ACPAs) are produced are fibrinogen and $\alpha$-enolase, which are abundantly present in the RA synovium [59, 60]. The presence of these autoantibodies is associated with a more aggressive disease course suggesting a pathogenic role in RA [61]. There is a large disease heterogeneity highlighted by different responses to medication such as the anti-TNF $\alpha$ antibodies.

During RA there is a massive influx of immune cells into the synovial cavity, including monocytes, macrophages, dendritic cells (DCs), T cells and B cells. Genetic evidence points towards an important role for APCs and their antigenuptake receptors in the pathogenesis of RA. The strongest association with RA susceptibility and disease severity has been found in the HLA-DRB1 gene [62-64]. Multiple RA risk alleles within the HLA-DRB1 gene share a conserved amino acid sequence and are therefore known as 'shared epitope' alleles [65]. These polymorphisms are present in the epitope binding region of the major histocompatibility complex II (MHC) and thereby probably influence antigen presentation by APCs and autoantibody production [66]. Recent data shows that shared epitope alleles of the MHC-II are specifically associated with anti-CCP positive RA [67, 68]. More recently also non-HLA genes have been linked to RA susceptibility and disease severity. Variants of the activating Fc gamma receptors Fc $\gamma R$ IIIIa and Fc $\gamma$ RIIIb have been associated with RA susceptibility in Europeans, but not in Asians $[69,70]$. The Fc $\gamma$ RIIIa variant is less effective in IC binding, implicating impaired clearance of ICs might play a role in the pathogenesis of RA, similar to SLE[71]. A functional variant of the inhibitory Fc $\gamma$ RIIb is associated with disease severity rather than susceptibility [72]. APCs from patients with this variant fail to develop an inhibitory phenotype upon IC binding, thereby stimulating pro-inflammatory immune responses and subsequent joint damage. Similar to SLE, the IRF5 and STAT4 genes are also important risk factors for RA [73, 74]. These genes are involved in the type I IFN system in APC, activated as a part of the TLR signaling pathway. These common denominators suggest that, like in SLE, the type I IFN system might play a role in the breaching of tolerance in RA. TLR involvement is further suggested by a functional variant of the TLR4 gene that reduces the response to LPS and thereby decreases the susceptibility to RA [75], although not significant in another study [76]. 
The involvement of APCs and their antigen uptake receptors in the pathogenesis of RA is not restricted to genetic predisposition, but is further supported by in vitro and in vivo data. In RA synovial tissue, the expression of TLR2, 3, 4 and 7 is increased compared to healthy controls or osteoarthritis patients [39, 77-79]. RA synovial fibroblasts produce increased amounts of chemokines upon stimulation with TLR2 ligands [80]. Similarly, monocyte-derived DCs from RA patients also show an increased responsiveness to TLR2 and TLR4 ligands, resulting in increased production of pro-inflammatory cytokines [39]. Tissue damage and cell stress during synovial inflammation can lead to the production of heat shock proteins (HSPs), altered fibronectin or low molecular weight hyaluronan fragments and RNA release from necrotic cells. These are endogenous TLR ligands that in turn can activate synovial fibroblasts and APCs via TLR2, TLR4 and TLR3, stimulating chronic inflammation [9, 78, 81-83]. Necrotic cells in the RA synovium may also release citrullinated proteins and activated citrullinating peptidylarginine deaminases (PADs). These enzymes can citrullinate for example fibrin(ogen) present in large amounts in the RA synovium. When these proteins are not degraded properly, they can be taken up by APCs and presented to T cells which in turn can trigger autoreactive B cells to produce ACPAs. Locally produced ICs can induce TNFa production by monocytes and macrophages via Fc $\gamma$ RIIa and thereby aggravate local inflammation and promote chronicity [84-86]. Recently, TLR8 has also been shown to be important for TNF $\alpha$ production in RA synovial tissue. Inhibition of TLR 8 was able to inhibit spontaneous TNF $\alpha$ production by RA synovial membrane cultures [87]. Stimulation of TLR8 by an unknown ssRNA containing component present in the RA synovium appears to lead to pro-inflammatory cytokine production, including type I IFNs, and might support APC maturation and subsequent presentation of (self) peptides to (autoreactive) $\mathrm{T}$ cells. These findings, together with genetic data concerning IRF5 and STAT4, are indicative of a role for type I IFNs in RA. Supportive of this are the high levels of IFN $\alpha$ found in RA synovial tissue and the selective up regulation of type I IFN-response genes in peripheral blood cells from a subgroup of RA patients $[10,88]$. In addition, it was recently reported that SLE features are common in RA patients given sufficient observation time and that these were associated with increased mortality [89]. Refuting a role for type I IFN in the pathogenesis of RA are the clinical advantages that have been made in RA using anti-TNF $\alpha$ antibodies. The production of type I IFN by plasmacytoid DCs is enhanced by blocking TNF $\alpha$ [90]. A known side effect of anti-TNF $\alpha$ therapy is the occurrence of antinuclear antibodies and anti-dsDNA antibodies which might even culminate in full-blown glomerulonephritis [91]. However, even antiTNF $\alpha$ therapy is successful in only a subpopulation of RA patients underscoring the existence of diverse pathways leading to autoimmunity. As in SLE, it might be possible that the endocytosis pathway by which the ssRNA is delivered to the intracellular TLR8 is mediated via antibodies and Fc $\gamma$ Rs. Immune complexes in joints might thus provide a direct link to cytokine dependent inflammation in RA, via APCs. Coherently, APCs from RA patients have been shown to produce more $\mathrm{TNF} \alpha$ upon IC triggering than healthy control APCs, which can be explained by increased expression of Fc $\gamma$ RII and FcyRIII on these cells [92, 93]. High expression of the inhibitory FcyRIIb could play an important role in controlling inflammation by inhibition of activating Fc $\gamma \mathrm{Rs}$ and TLR4 induced cytokine production in macrophages and DCs $[5,94]$. Highly increased Fc $\gamma$ RIIb expression on monocyte-derived DCs from RA patients that have sustained low disease activity without the need of medication underscores the importance of this feedback mechanism in RA [5].

Fc $\gamma R$ knockout studies confirm the important role of Fc $\gamma R$ s in arthritis. Several studies have shown that the presence of activating $F c \gamma R s$ was associated with increased chondrocyte death and cartilage erosion and that FcyRIII knockout mice are protected from IC-induced arthritis[9599]. Inhibition of spleen tyrosine kinase (Syk), a key mediator of activating FcyRs and B cell receptor signaling, also shows suppression of inflammation and bone erosion, highlighting a possible role of activating FcyRs in arthritis models [100]. On the other hand, deletion of the inhibitory FcyRII (mice lack FcyRIIa) induced arthritis even in nonsusceptible mice [101]. FcyRIIb not only inhibits activating Fc $\gamma R s$, but is also important for effective clearance of ICs [102]. Furthermore, Fc $\gamma$ RIIa transgenic mice are hyperresponsive to pathogenic antibodies and blocking of this receptor in these mice inhibited development and stopped progression of collagen-induced arthritis [103]. These data clearly show the importance of activating Fc $\gamma$ Rs on APCs in the initiation and progression of arthritis, which is in line with the in vitro data showing involvement of activating Fc $\gamma$ Rs in pro-inflammatory cytokine production and inhibition of this by FcyRIIb. Experimental arthritis models have also contributed to our understanding of the role of TLRs in RA. Classical animal models such as streptococcal cell wall (SCW) arthritis and autoimmune arthritis in IL-1 receptor antagonist-knockout (IL-1ra-/-) mice are dependent on activation of the innate immune system via TLRs. The acute phase of SCW induced arthritis is dependent of TLR2, while the TLR dependency shifts towards TLR4 in the chronic phase. This occurs simultaneously with the transition from a macrophage driven arthritis to a $\mathrm{T}$ cell dependent process [102]. Arthritis development in IL-1ra -/- mice can also be regulated by TLRs, since TLR2 knockout mice develop a more severe arthritis while TLR4 knockouts were protected against severe arthritis. Selective blocking of TLR4 was also able to diminish severity of experimental arthritis [104]. A role for TLRs is further supported by studies that show a self-limited form of arthritis in mice after synovial injection of TLR ligands, such as CpG DNA, dsRNA or staphylococcal peptidoglycans [105-107].

APCs and their cytokines have been proven to be an effective therapeutic target in the treatment of RA. Therapies often used now are biologicals directed against effector molecules like TNF $\alpha$ (adalimumab, etanercept, and infliximab), IL-6 (tocilizumab) or IL-1 (anakinra), molecules produced by APCs as a response to TLR stimulation or antigen uptake via Fc $\gamma$ Rs. The development of TNF $\alpha$ antagonists had a great impact on treatment of RA patients, although still about $30 \%$ of the patients fails to respond to TNF antagonists or has to discontinue treatment due to adverse effects [108, 109]. Another effective therapy directed against APCs is abatacept, which binds to CD80/CD86 on the APC and prevents T cell activation [110-112]. Medication more specifically directed against antigen-uptake receptors or TLRs are already used for several years and more are under investiga- 
tion. The combination of methotrexate and hydroxychloroquine, which prevents intracellular TLR activation, shows increased effectiveness compared to methotrexate alone [113-116], although this might partially be due to an increased bioavailability of methotrexate [117]. The effectiveness of direct targeting of TLRs in RA is also supported by a phase II clinical trial with chaperonin 10, that inhibits TLR2 and TLR4 signaling [118]. No placebo was used in this trial, so confirmation of its potential is necessary, but it suggests quick and sustained improvement of symptoms during the 12 weeks follow up. However, there are some considerations concerning possible adverse effects during long-term use, since chaperonin 10 has also been described in carcinogenesis $[119,120]$. Long term studies have to show if chaperonin 10 could be used in the treatment of RA or not. Since Syk is involved in Fc $\gamma \mathrm{R}$ and B cell receptor signaling inhibition of this tyrosine kinase could reduce IC mediated inflammation and B cell responses, suggesting great potential in RA treatment. A 12 week, randomized clinical trial has already demonstrated superior clinical efficacy of an oral Syk kinase inhibitor, R788 compared to placebo [121].

\section{SYSTEMIC SCLEROSIS}

Systemic sclerosis $(\mathrm{SSc})$ is a heterogenous autoimmune disease characterized by fibrosis of the skin and the internal organs, leading to sever debilitation and eventually death. The prevalence and incidence of SSc varies greatly depending on geographical location and ethnicity but it is clear that women are affected more often than men with a ratio ranging from 4:1 to 14:1 [122]. Over the past year clinical outcomes have improved, presumable due to better management of complications, but still SSc is considered incurable. As most autoimmune diseases SSc is a heterogeneous disease. Clinically it can be subdivided in two entities on the extent of skin involvement; limited SSc (limSSc) defined as fibrosis distal to the elbow and knee joint and the face, and the diffuse form with more proximal fibrosis [2]. The diffuse cutaneous form (dSSc) is the most fatal connective tissue disease known with 55\% survival at 10 years [123]. The etiology is still unknown but prominent features are vascular injury and chronic inflammation resulting in fibrosis. Evidence for an autoimmune process causing this inflammation is growing, for example exposed by the presence of auto-antibodies in $90 \%$ of SSc patients.

As for the autoimmune diseases described above, the genetic make-up seems to determine the chance of developing SSc in response to an external trigger. This is demonstrated by the fact that a positive family history is the strongest risk factor thus far identified in SSc [124] although concordance is still weak [125]. Furthermore SSc is now associated with a sizable number of SNPs in an increasing number of genes [126]. Like in other autoimmune diseases the HLA region is a region of interest in SSc. However there is a lack of consensus concerning the contribution of these alleles in SSc. A consistent finding in this discussion seems to be the association between anti-topoisomerase I (anti-topo I) and the HLA-DR region [127-129] suggesting a contribution of auto-antibodies in the pathogenesis. As reported in SLE and RA there is an association between the possession of the SNP rs2004640 in IRF5 and susceptibility to SSc [130] (and unpublished observations). This SNP results in the production of a different isotype from IRF5 leading to a different transcription of target pro-inflammatory cytokines which are known to increase the risk for developing SLE [131]. Next to that, recent data show an association between STAT-4 SNPs and disease phenotype favoring limited SSc [132]. Both associations suggest a role for TLR signaling and the IFN pathway in SSc as shown for SLE and RA but further research to unravel consequences of these SNPs is needed.

Anti-topo I and anti-centromere antibodies (ACA) are generally known to characterize specific clinical subsets with Anti-topo I being more prevalent in dSSc and ACA in limSSc [133]. In line with findings in SLE, data on an IFN type I signature are growing [134-136] and a recent report from Kim et al. [137] showed interferogenic activity by antitopo I ICs. Although a role for type I IFNs in SSc is counterintuitive knowing that these IFN are potent inhibitors of collagen production in fibroblasts [138], a report describing the rapid onset of SSc symptoms in patients treated with intense IFN $\alpha$ therapy suggests a clear pathologic contribution of IFNs to the development of SSc [139]. In view of this, plasmacytoid DC (pDCs) are interesting due to their potential of producing high levels of type I IFNs. Kim et al. showed that interfering with Fc $\gamma$ RIIa or RNAse treatment suppresses the IFN $\alpha$ production upon stimulation with anti-topo I antibodies [137]. This implicates that like anti-Sm antibodies in SLE, anti-topo I antibodies are taken up by pDCs via FcyRIIa and subsequently activate TLR7 inducing the production of IFN $\alpha$. In contrast, ACA did not induce the production of IFN $\alpha$. Since anti-topo I and ACA are predominantly found in patients with dSSc and limSSc, respectively, a role for IFN $\alpha$ in disease severity seems likely. Type I IFNs have a known anti-angiogenic and pro-apoptotic effect on endothelial cells implicating a role in SSc vascular distress. Highlighting this, endothelial cells in SSc express a type I interferon signature $[134,140]$. In the last years more autoantibodies were identified and their contribution to the disease was investigated. For example, antibodies directed against Fc $\gamma \mathrm{R}$ and especially Fc $\gamma \mathrm{RIII}$ were described. This was suggested to reduce the ability of Fc $\gamma R$ to phagocytose immune complexes [141, 142]. Other antibodies target fibroblasts (anti-fibroblast antibodies (AFA) and anti-plateletderived growth factor (PDGF) receptor) [143]. Stimulation of fibroblasts through TLR4, possibly by these autoantibodies, up regulates a chemokine transcription program, skewed towards pro-fibrotic activities, for example increased CCL2 production. The importance of this is illustrated by the fact that CCL2 is abundantly present in SSc [144-147] and most interestingly CCR2-/- mice are resistant to the development of lung fibrosis induced by bleomycin [148]. More intriguing recent literature suggests that signaling through TLRs plays a role in maintaining the heightened state of activation of the myofibroblast as seen during fibrosis [149]. These findings together with the presence of endogenous TLR4 ligands in the circulation of SSc patients [39] suggests that signaling through these receptors could induce chronic systemic fibrosis in the susceptible host.

An initial pathological finding in SSc dermal tissue is rarefaction of capillaries and the infiltration of mononuclear cells $[150,151]$. These cellular infiltrates consist mainly of myeloid APCs and $\mathrm{CD}^{+}{ }^{+} \mathrm{T}$-cells. The role of the immune system in the development of SSc has been investigated in several animal models. In UCD 200 chicken, for example, dermal and visceral fibrosis is also preceded by mononuclear 
infiltration demonstrating the role of inflammatory cells in initiating fibrosis [152, 153]. Thight Skin-2 mice (Tsk-2), another SSc animal model, also show this early mononuclear cell infiltration together with autoantibody production resembling human SSc $[154,155]$. Bleomycin is a glycopeptide antibiotic used as a chemotherapeutic agent, well-known side effects are lung fibrosis and Raynaud's phenomenon. Repeated subcutaneous injections of bleomycin in shaved back skin induced dermal fibrosis closely resembling SSc [156]. In the murine bleomycin model immune cells are activated by hyaluronan via TLR4 (and directly by bleomycin via TLR2 [157]) and auto-antibody production is induced resulting in a scleroderma like phenotype [158].

The increasing amount of evidence illustrating the role of APCs in the pathogenesis of SSc can offer new insights in the pathogenesis of this disease and thus offer new therapeutic targets. As an example, the data above suggest that in SSc APCs infiltrate the diseased tissue, are activated through their TLRs and activate a cascade resulting in fibrosis. Interfering in this cascade is just one interesting example. A therapeutic target might be BDCA-2, a C-type lectin receptor exclusively present on pDCs. Ligation of BDCA-2 inhibits the production of type I IFN of pDCs upon anti-topo I stimulation by interfering with the uptake via FcyRIIa and signaling through TLRs [137]. Activation of pDC via BDCA-2 might thus reduce the pro-inflammatory and anti-angiogenic effect of these ICs. Current therapeutic options in SSc are very limited. Administrations of cyclophosphamide or autologous stem cell transplantation currently are the only therapies with some effect [159], although the results of the bigger trials are still to be expected [160]. As these therapies attack the whole cellular balance it is impossible to speculate on a specific contribution.

\section{CONCLUSION}

A large body of evidence points towards a seminal role for APCs and their uptake receptors in the development of autoimmune diseases. Striking similarities in many genetic and pathophysiological features in autoimmune diseases like SLE, RA and SSc were described despite their apparent dissimilar characteristics (Table 1). A fitting explanation for this issue appears to be the HLA-DRB1 gene which is associated with all these diseases. Since there is almost no over-

Table 1. Highlighting Some Current Data Available on the Role Played by APCs, their Fc $\gamma$ Rs and TLRs and their Products

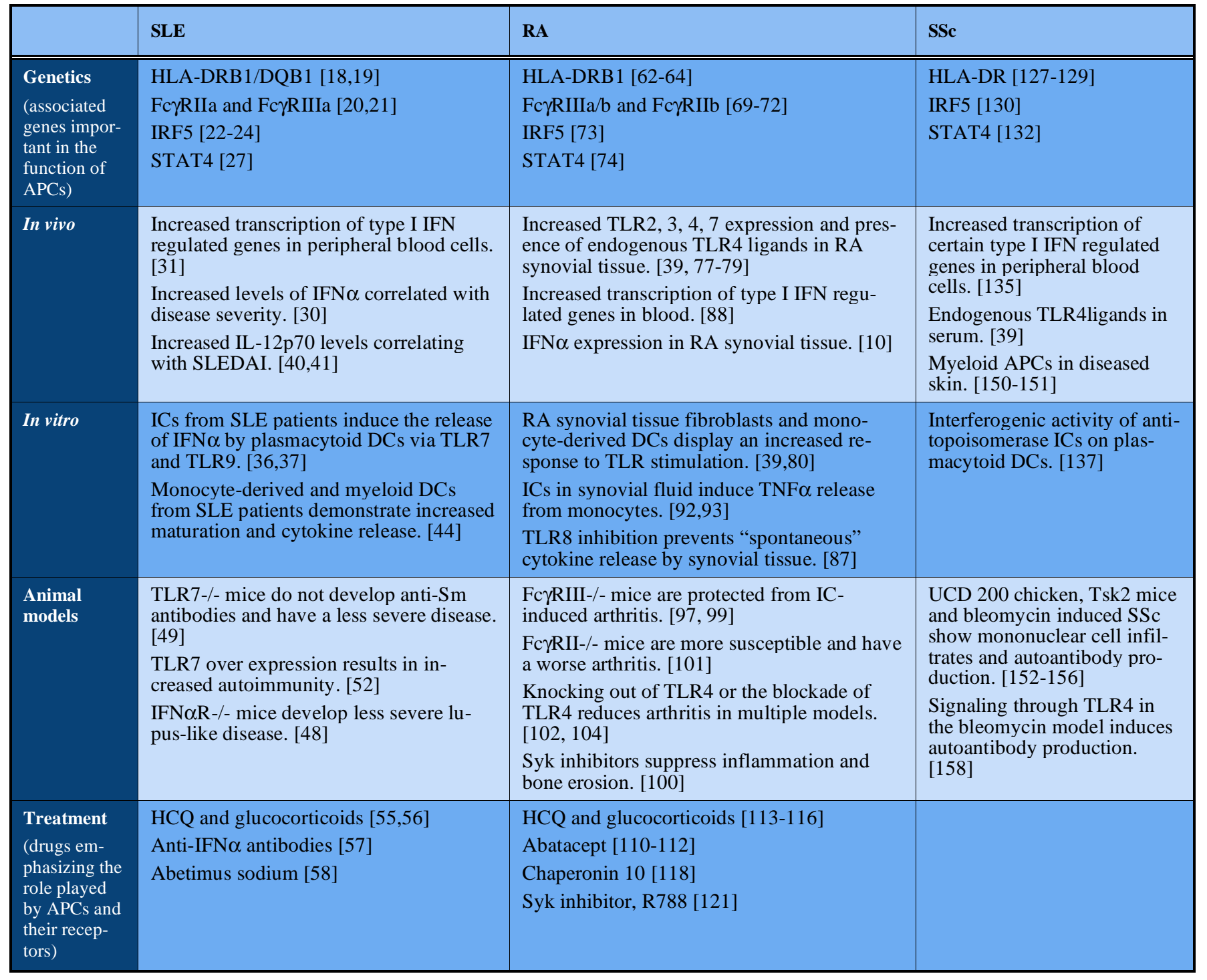


lap between the polymorphisms within this gene [161] and most are located within the epitope binding region, the MHC-II variant probably determines the antigen against which auto-antibodies are produced and thus which clinical phenotype occurs. Fc $\gamma$ Rs and TLRs expressed by APCs are crucial receptors of the immune system forming a bridge between innate and adaptive immunity. In autoimmunity these receptors appear to direct immune responses towards self by enabling the uptake of immune complexes containing (nucleic) self-antigens. These ICs induce the release of proinflammatory cytokines, such as type I IFNs, by APCs and forces them to mature. These mature APCs then induce the differentiation and proliferation of auto-reactive $\mathrm{T}$ cells, a crucial event in the pathogenesis of autoimmunity. Next to this the type I IFN system is unequivocally entangled in the pathogenesis of SLE and appears to have contributing roles to both RA and SSc. These findings underscore the potential of treatments aimed at APCs. Accordingly, in the past, present and future the most promising targets in the enduring battle against autoimmunity appear to be these cells themselves, their receptors and their products.

\section{REFERENCES}

[1] Hochberg MC. Updating the American College of Rheumatology revised criteria for the classification of systemic lupus erythematosus. Arthritis Rheum 1997; 40: 1725.

[2] LeRoy EC, Black C, Fleischmajer R, et al. Scleroderma (systemic sclerosis); classification, subsets and pathogenesis. J Rheumatol 1988; 15: 202-5.

[3] Arnett FC, Edworthy SM, Bloch DA, et al. The American Rheumatism Association 1987 revised criteria for the classification of rheumatoid arthritis. Arthritis Rheum 1988; 31: 315-24.

[4] Boruchov AM, Heller G, Veri MC, Bonvini E, Ravetch JV, Young JW. Activating and inhibitory $\mathrm{IgG} F \mathrm{Fc}$ receptors on human DCs mediate opposing functions. J Clin Invest 2005; 115: 2914-23.

[5] Wenink MH, Santegoets KC, Roelofs MF, et al. The inhibitory $\mathrm{Fc}$ (gamma)Ilb receptor dampens TLR4-mediated immune responses and is selectively up-regulated on dendritic cells from rheumatoid arthritis patients with quiescent disease. J Immunol 2009; 183: 4509-20.

[6] Ronnblom L, Eloranta ML, Alm GV. The type I interferon system in systemic lupus erythematosus. Arthritis Rheum 2006; 54: 40820.

[7] Martin DA, Elkon KB. Autoantibodies make a U-turn; the toll hypothesis for autoantibody specificity. J Exp Med 2005; 202: 1465-9.

[8] Deane JA, Bolland S. Nucleic acid-sensing TLRs as modifiers of autoimmunity. J Immunol 2006; 177: 6573-8.

[9] Roelofs MF, Boelens WC, Joosten LA, et al. Identification of small heat shock protein B8 (HSP22) as a novel TLR4 ligand and potential involvement in the pathogenesis of rheumatoid arthritis. J Immunol 2006; 176: 7021-7.

[10] Roelofs MF, Wenink MH, Brentano F, et al. Type I interferons might form the link between Toll-like receptor (TLR) 3/7 and TLR4 mediated synovial inflammation in rheumatoid arthritis (RA). Ann Rheum Dis 2009; 68(9): 1486-93.

[11] Eriksson U, Ricci R, Hunziker L, et al. Dendritic cell-induced autoimmune heart failure requires cooperation between adaptive and innate immunity. Nat Med 2003; 9: 1484-90.

[12] Marshak-Rothstein A. Toll-like receptors in systemic autoimmune disease. Nat Rev Immunol 2006; 6: 823-35.

[13] Ronnblom L, Pascual V. The innate immune system in SLE; type I interferons and dendritic cells. Lupus 2008; 17: 394-9.

[14] Lafyatis R, Marshak-Rothstein A. Toll-like receptors and innate immune responses in systemic lupus erythematosus. Arthritis Res Ther 2007; 9: 222.

[15] D'Cruz DP, Khamashta MA, Hughes GR. Systemic lupus erythematosus. Lancet 2007; 369: 587-96.

[16] Neogi T, Gladman DD, Ibanez D, Urowitz M. Anti-dsDNA antibody testing by Farr and ELISA techniques is not equivalent. $\mathbf{J}$ Rheumatol 2006; 33: 1785-8.

[17] Criswell LA. The genetic contribution to systemic lupus erythematosus. Bull NYU Hosp Jt Dis 2008; 66: 176-83.
[18] Graham RR, Ortmann W, Rodine P, et al. Specific combinations of HLA-DR2 and DR3 class II haplotypes contribute graded risk for disease susceptibility and autoantibodies in human SLE. Eur J Hum Genet 2007; 15: 823-30.

[19] Fernando MM, Stevens CR, Sabeti PC, et al. Identification of two independent risk factors for lupus within the MHC in United Kingdom families. PLoS Genet 2007; 3: e192.

[20] Karassa FB, Trikalinos TA, Ioannidis JP. Role of the Fcgamma receptor IIa polymorphism in susceptibility to systemic lupus erythematosus and lupus nephritis; a meta-analysis. Arthritis Rheum 2002; 46: 1563-71.

[21] Karassa FB, Trikalinos TA, Ioannidis JP. The Fe gamma RIIIAF158 allele is a risk factor for the development of lupus nephritis; a meta-analysis. Kidney Int 2003; 63: 1475-82.

[22] Ferreiro-Neira I, Calaza M, Alonso-Perez E, et al. Opposed independent effects and epistasis in the complex association of IRF5 to SLE. Genes Immun 2007; 8: 429-38.

[23] Castro J, Balada E, Ordi-Ros J, Vilardell-Tarres M. The complex immunogenetic basis of systemic lupus erythematosus. Autoimmun Rev 2008; 7: 345-51.

[24] Kozyrev SV, Lewen S, Reddy PM, et al. Structural insertion/deletion variation in IRF5 is associated with a risk haplotype and defines the precise IRF5 isoforms expressed in systemic lupus erythematosus. Arthritis Rheum 2007; 56: 1234-41.

[25] Graham RR, Kozyrev SV, Baechler EC, et al. A common haplotype of interferon regulatory factor 5 (IRF5) regulates splicing and expression and is associated with increased risk of systemic lupus erythematosus. Nat Genet 2006; 38: 550-5.

[26] Yasuda K, Richez C, Uccellini MB, et al. Requirement for DNA CpG content in TLR9-dependent dendritic cell activation induced by DNA-containing immune complexes. J Immunol 2009; 183: 3109-17.

[27] Sigurdsson S, Nordmark G, Garnier S, et al. A risk haplotype of STAT4 for systemic lupus erythematosus is over-expressed, correlates with anti-dsDNA and shows additive effects with two risk alleles of IRF5. Hum Mol Genet 2008; 17: 2868-76.

[28] Longman RS, Braun D, Pellegrini S, Rice CM, Darnell RB, Albert ML. Dendritic-cell maturation alters intracellular signaling networks, enabling differential effects of IFN-alpha/beta on antigen cross-presentation. Blood 2007; 109: 1113-22.

[29] Chang HC, Han L, Goswami R, et al. Impaired development of human Th1 cells in patients with deficient expression of STAT4. Blood 2009; 113(23): 5887-90.

[30] Bengtsson AA, Sturfelt G, Truedsson L, et al. Activation of type I interferon system in systemic lupus erythematosus correlates with disease activity but not with antiretroviral antibodies. Lupus 2000; 9: 664-71.

[31] Baechler EC, Batliwalla FM, Karypis G, et al. Interferon-inducible gene expression signature in peripheral blood cells of patients with severe lupus. Proc Natl Acad Sci USA 2003; 100: 2610-5.

[32] Boule MW, Broughton C, Mackay F, Akira S, Marshak-Rothstein A, Rifkin IR. Toll-like receptor 9-dependent and -independent dendritic cell activation by chromatin-immunoglobulin $\mathrm{G}$ complexes. J Exp Med 2004; 199: 1631-40.

[33] Vallin H, Blomberg S, Alm GV, Cederblad B, Ronnblom L. Patients with systemic lupus erythematosus (SLE) have a circulating inducer of interferon-alpha (IFN-alpha) production acting on leucocytes resembling immature dendritic cells. Clin Exp Immunol 1999; 115: 196-202.

[34] Bave U, Alm GV, Ronnblom L. The combination of apoptotic U937 cells and lupus IgG is a potent IFN-alpha inducer. J Immunol 2000; 165: 3519-26.

[35] Leadbetter EA, Rifkin IR, Hohlbaum AM, Beaudette BC, Shlomchik MJ, Marshak-Rothstein A. Chromatin-IgG complexes activate B cells by dual engagement of IgM and Toll-like receptors. Nature 2002; 416: 603-7.

[36] Means TK, Latz E, Hayashi F, Murali MR, Golenbock DT, Luster AD. Human lupus autoantibody-DNA complexes activate DCs through cooperation of CD32 and TLR9. J Clin Invest 2005; 115: 407-17.

[37] Savarese E, Chae OW, Trowitzsch S, et al. U1 small nuclear ribonucleoprotein immune complexes induce type I interferon in plasmacytoid dendritic cells through TLR7. Blood 2006; 107: 3229-34.

[38] Napolitani G, Rinaldi A, Bertoni F, Sallusto F, Lanzavecchia A. Selected Toll-like receptor agonist combinations synergistically trigger a $\mathrm{T}$ helper type 1-polarizing program in dendritic cells. Nat Immunol 2005; 6: 769-76.

[39] Roelofs MF, Joosten LA, Abdollahi-Roodsaz S, et al. The expression of toll-like receptors 3 and 7 in rheumatoid arthritis synovium is increased and costimulation of toll-like receptors 3,4 , and $7 / 8$ re- 
sults in synergistic cytokine production by dendritic cells. Arthritis Rheum 2005; 52: 2313-22.

[40] Tokano Y, Morimoto S, Kaneko H, et al. Levels of IL-12 in the sera of patients with systemic lupus erythematosus (SLE)--relation to Th1- and Th2-derived cytokines. Clin Exp Immunol 1999; 116: 169-73.

[41] Wong CK, Lit LC, Tam LS, Li EK, Wong PT, Lam CW. Hyperproduction of IL-23 and IL-17 in patients with systemic lupus erythematosus; implications for Th17-mediated inflammation in auto-immunity. Clin Immunol 2008; 127: 385-93.

[42] Sugimoto K, Morimoto S, Kaneko H, et al. Decreased IL-4 producing CD4+ $\mathrm{T}$ cells in patients with active systemic lupus erythematosus-relation to IL-12R expression. Autoimmunity 2002; 35: 3817.

[43] Ozmen L, Roman D, Fountoulakis M, Schmid G, Ryffel B, Garotta G. Experimental therapy of systemic lupus erythematosus; the treatment of NZB/W mice with mouse soluble interferon-gamma receptor inhibits the onset of glomerulonephritis. Eur J Immunol 1995; 25: 6-12.

[44] Ding D, Mehta H, McCune WJ, Kaplan MJ. Aberrant phenotype and function of myeloid dendritic cells in systemic lupus erythematosus. J Immunol 2006; 177: 5878-89.

[45] Blanco P, Palucka AK, Gill M, Pascual V, Banchereau J. Induction of dendritic cell differentiation by IFN-alpha in systemic lupus erythematosus. Science 2001; 294: 1540-3.

[46] Jego G, Palucka AK, Blanck JP, Chalouni C, Pascual V, Banchereau J. Plasmacytoid dendritic cells induce plasma cell differentiation through type I interferon and interleukin 6. Immunity 2003; 19: 225-34.

[47] Pisitkun P, Deane JA, Difilippantonio MJ, Tarasenko T, Satterthwaite AB, Bolland S. Autoreactive B cell responses to RNA-related antigens due to TLR7 gene duplication. Science 2006; 312: 1669-72.

[48] Santiago-Raber ML, Baccala R, Haraldsson KM, et al. Type-I interferon receptor deficiency reduces lupus-like disease in NZB mice. J Exp Med 2003; 197: 777-88.

[49] Christensen SR, Shupe J, Nickerson K, Kashgarian M, Flavell RA, Shlomchik MJ. Toll-like receptor 7 and TLR9 dictate autoantibody specificity and have opposing inflammatory and regulatory roles in a murine model of lupus. Immunity 2006; 25: 417-28.

[50] Pawar RD, Ramanjaneyulu A, Kulkarni OP, Lech M, Segerer S, Anders HJ. Inhibition of Toll-like receptor-7 (TLR-7) or TLR-7 plus TLR-9 attenuates glomerulonephritis and lung injury in experimental lupus. J Am Soc Nephrol 2007; 18: 1721-31.

[51] Barrat FJ, Meeker T, Chan JH, Guiducci C, Coffman RL. Treatment of lupus-prone mice with a dual inhibitor of TLR7 and TLR9 leads to reduction of autoantibody production and amelioration of disease symptoms. Eur J Immunol 2007; 37: 3582-6.

[52] Subramanian S, Tus K, Li QZ, et al. A Tlr7 translocation accelerates systemic autoimmunity in murine lupus. Proc Natl Acad Sci USA 2006; 103: 9970-5.

[53] Pawar RD, Patole PS, Ellwart A, et al. Ligands to nucleic acidspecific toll-like receptors and the onset of lupus nephritis. J Am Soc Nephrol 2006; 17: 3365-73.

[54] Ma Z, Chen F, Madaio MP, Cohen PL, Eisenberg RA. Modulation of autoimmunity by TLR9 in the chronic graft-vs-host model of systemic lupus erythematosus. J Immunol 2006; 177: 7444-50.

[55] Bennett L, Palucka AK, Arce E, et al. Interferon and granulopoiesis signatures in systemic lupus erythematosus blood. J Exp Med 2003; 197: 711-23.

[56] Lebon P. Inhibition of herpes simplex virus type 1-induced interferon synthesis by monoclonal antibodies against viral glycoprotein $\mathrm{D}$ and by lysosomotropic drugs. J Gen Virol 1985; 66(Pt12): 27816 .

[57] Wallace DJ. MEDI-545, an anti-interferon alpha monoclonal antibody, shows evidence of clinical activity in systemic lupus erythematosus. ACR/ARHP Scientific Meeting: Boston 2007.

[58] Cardiel MH, Tumlin JA, Furie RA, Wallace DJ, Joh T, Linnik MD. Abetimus sodium for renal flare in systemic lupus erythematosus; results of a randomized, controlled phase III trial. Arthritis Rheum 2008; 58: 2470-80.

[59] Zhao X, Okeke NL, Sharpe O, et al. Circulating immune complexes contain citrullinated fibrinogen in rheumatoid arthritis. Arthritis Res Ther 2008; 10: R94.

[60] Kinloch A, Lundberg K, Wait R, et al. Synovial fluid is a site of citrullination of autoantigens in inflammatory arthritis. Arthritis Rheum 2008; 58: 2287-95.

[61] Turesson C, Jacobsson LT, Sturfelt G, Matteson EL, Mathsson L, Ronnelid J. Rheumatoid factor and antibodies to cyclic citrullinated peptides are associated with severe extra-articular manifestations in rheumatoid arthritis. Ann Rheum Dis 2007; 66: 59-64.
[62] Stastny P. Association of the B-cell alloantigen DRw4 with rheumatoid arthritis. N Engl J Med 1978; 298: 869-71.

[63] Stastny P. Mixed lymphocyte cultures in rheumatoid arthritis. J Clin Invest 1976; 57: 1148-57.

[64] Gorman JD, Lum RF, Chen JJ, Suarez-Almazor ME, Thomson G, Criswell LA. Impact of shared epitope genotype and ethnicity on erosive disease; a meta-analysis of 3,240 rheumatoid arthritis patients. Arthritis Rheum 2004; 50: 400-12.

[65] Gregersen PK, Silver J, Winchester RJ. The shared epitope hypothesis. An approach to understanding the molecular genetics of susceptibility to rheumatoid arthritis. Arthritis Rheum 1987; 30: 1205-13.

[66] Hill JA, Southwood S, Sette A, Jevnikar AM, Bell DA, Cairns E. Cutting edge; the conversion of arginine to citrulline allows for a high-affinity peptide interaction with the rheumatoid arthritisassociated HLA-DRB $1 * 0401$ MHC class II molecule. J Immunol 2003; 171: 538-41.

[67] Huizinga TW, Amos CI, van der Helm-van Mil AH, et al. Refining the complex rheumatoid arthritis phenotype based on specificity of the HLA-DRB1 shared epitope for antibodies to citrullinated proteins. Arthritis Rheum 2005; 52: 3433-8.

[68] Ding B, Padyukov L, Lundstrom E, et al. Different patterns of associations with anti-citrullinated protein antibody-positive and anti-citrullinated protein antibody-negative rheumatoid arthritis in the extended major histocompatibility complex region. Arthritis Rheum 2009; 60: 30-8

[69] Alizadeh BZ, Valdigem G, Coenen MJ, et al. Association analysis of functional variants of the FcgRIIa and FcgRIIIa genes with type 1 diabetes, celiac disease and rheumatoid arthritis. Hum Mol Genet 2007; 16: 2552-9.

[70] Lee YH, Ji JD, Song GG. Associations between FCGR3A polymorphisms and susceptibility to rheumatoid arthritis; a metaanalysis. J Rheumatol 2008; 35: 2129-35.

[71] Bruhns P, Iannascoli B, England P, et al. Specificity and affinity of human Fcgamma receptors and their polymorphic variants for human IgG subclasses. Blood 2009; 113: 3716-25.

[72] Radstake TR, Franke B, Wenink MH, et al. The functional variant of the inhibitory Fcgamma receptor IIb (CD32B) is associated with the rate of radiologic joint damage and dendritic cell function in rheumatoid arthritis. Arthritis Rheum 2006; 54: 3828-37.

[73] Dieguez-Gonzalez R, Calaza M, Perez-Pampin E, et al. Association of interferon regulatory factor 5 haplotypes, similar to that found in systemic lupus erythematosus, in a large subgroup of patients with rheumatoid arthritis. Arthritis Rheum 2008; 58: 1264-74.

[74] Remmers EF, Plenge RM, Lee AT, et al. STAT4 and the risk of rheumatoid arthritis and systemic lupus erythematosus. N Engl J Med 2007; 357: 977-86.

[75] Radstake TR, Franke B, Hanssen S, et al. The Toll-like receptor 4 Asp299Gly functional variant is associated with decreased rheumatoid arthritis disease susceptibility but does not influence disease severity and/or outcome. Arthritis Rheum 2004; 50: 999-1001.

[76] Sanchez E, Orozco G, Lopez-Nevot MA, Jimenez-Alonso J, Martin J. Polymorphisms of toll-like receptor 2 and 4 genes in rheumatoid arthritis and systemic lupus erythematosus. Tissue Antigens 2004; 63: 54-7.

[77] Radstake TR, Roelofs MF, Jenniskens YM, et al. Expression of toll-like receptors 2 and 4 in rheumatoid synovial tissue and regulation by proinflammatory cytokines interleukin-12 and interleukin18 via interferon-gamma. Arthritis Rheum 2004; 50: 3856-65.

[78] Brentano F, Schorr O, Gay RE, Gay S, Kyburz D. RNA released from necrotic synovial fluid cells activates rheumatoid arthritis synovial fibroblasts via Toll-like receptor 3. Arthritis Rheum 2005; 52: 2656-65.

[79] Ospelt C, Brentano F, Rengel Y, et al. Overexpression of toll-like receptors 3 and 4 in synovial tissue from patients with early rheumatoid arthritis; toll-like receptor expression in early and longstanding arthritis. Arthritis Rheum 2008; 58: 3684-92.

[80] Pierer M, Rethage J, Seibl R, et al. Chemokine secretion of rheumatoid arthritis synovial fibroblasts stimulated by Toll-like receptor 2 ligands. J Immunol 2004; 172: 1256-65.

[81] Vabulas RM, Ahmad-Nejad P, da Costa C, et al. Endocytosed HSP60s use toll-like receptor 2 (TLR2) and TLR4 to activate the toll/interleukin-1 receptor signaling pathway in innate immune cells. J Biol Chem 2001; 276: 31332-9.

[82] Termeer C, Benedix F, Sleeman J, et al. Oligosaccharides of Hyaluronan activate dendritic cells via toll-like receptor 4. J Exp Med 2002; 195: 99-111.

[83] Okamura Y, Watari M, Jerud ES, et al. The extra domain A of fibronectin activates Toll-like receptor 4. J Biol Chem 2001; 276: 10229-33. 
[84] Clavel C, Nogueira L, Laurent L, et al. Induction of macrophage secretion of tumor necrosis factor alpha through Fcgamma receptor IIa engagement by rheumatoid arthritis-specific autoantibodies to citrullinated proteins complexed with fibrinogen. Arthritis Rheum 2008; 58: 678-88.

[85] van Venrooij WJ, Pruijn GJ. An important step towards completing the rheumatoid arthritis cycle. Arthritis Res Ther 2008; 10: 117.

[86] Mathsson L, Lampa J, Mullazehi M, Ronnelid J. Immune complexes from rheumatoid arthritis synovial fluid induce FcgammaRIIa dependent and rheumatoid factor correlated production of tumour necrosis factor-alpha by peripheral blood mononuclear cells. Arthritis Res Ther 2006; 8: R64.

[87] Sacre SM, Lo A, Gregory B, et al. Inhibitors of TLR8 reduce TNF production from human rheumatoid synovial membrane cultures. J Immunol 2008; 181: 8002-9.

[88] van der Pouw Kraan TC, Wijbrandts CA, van Baarsen LG, et al. Rheumatoid arthritis subtypes identified by genomic profiling of peripheral blood cells; assignment of a type I interferon signature in a subpopulation of patients. Ann Rheum Dis 2007; 66: 1008-14.

[89] Icen M, Nicola PJ, Maradit-Kremers H, et al. Systemic lupus erythematosus features in rheumatoid arthritis and their effect on overall mortality. J Rheumatol 2009; 36: 50-7.

[90] Palucka AK, Blanck JP, Bennett L, Pascual V, Banchereau J. Cross-regulation of TNF and IFN-alpha in autoimmune diseases. Proc Natl Acad Sci USA 2005; 102: 3372-7.

[91] Stokes MB, Foster K, Markowitz GS, et al. Development of glomerulonephritis during anti-TNF-alpha therapy for rheumatoid arthritis. Nephrol Dial Transplant 2005; 20: 1400-6.

[92] Blom AB, Radstake TR, Holthuysen AE, et al. Increased expression of Fcgamma receptors II and III on macrophages of rheumatoid arthritis patients results in higher production of tumor necrosis factor alpha and matrix metalloproteinase. Arthritis Rheum 2003; 48: 1002-14.

[93] Radstake TR, Blom AB, Sloetjes AW, et al. Increased FcgammaRII expression and aberrant tumour necrosis factor alpha production by mature dendritic cells from patients with active rheumatoid arthritis. Ann Rheum Dis 2004; 63: 1556-63.

[94] Zhang Y, Liu S, Liu J, et al. Immune complex/Ig negatively regulate TLR4-triggered inflammatory response in macrophages through Fc gamma RIIb-dependent PGE2 production. J Immunol 2009; 182: 554-62.

[95] Blom AB, van Lent PL, van Vuuren H, et al. Fc gamma R expression on macrophages is related to severity and chronicity of synovial inflammation and cartilage destruction during experimental immune-complex-mediated arthritis (ICA). Arthritis Res 2000; 2: 489-503.

[96] van Lent PL, van Vuuren AJ, Blom AB, et al. Role of Fc receptor gamma chain in inflammation and cartilage damage during experimental antigen-induced arthritis. Arthritis Rheum 2000; 43: 74052.

[97] van Lent PL, Nabbe K, Blom AB, et al. Role of activatory Fc gamma RI and Fc gamma RIII and inhibitory Fc gamma RII in inflammation and cartilage destruction during experimental antigeninduced arthritis. Am J Pathol 2001; 159: 2309-20.

[98] Nabbe KC, van Lent PL, Holthuysen AE, Kolls JK, Verbeek S, van den Berg WB. FcgammaRI up-regulation induced by local adenoviral-mediated interferon-gamma production aggravates chondrocyte death during immune complex-mediated arthritis. Am J Pathol 2003; 163: 743-52.

[99] Diaz de Stahl T, Andren M, Martinsson P, Verbeek JS, Kleinau S. Expression of FcgammaRIII is required for development of collagen-induced arthritis. Eur J Immunol 2002; 32: 2915-22.

[100] Pine PR, Chang B, Schoettler N, et al. Inflammation and bone erosion are suppressed in models of rheumatoid arthritis following treatment with a novel Syk inhibitor. Clin Immunol 2007; 124: 244-57.

[101] Yuasa T, Kubo S, Yoshino T, et al. Deletion of fcgamma receptor IIB renders H-2(b) mice susceptible to collagen-induced arthritis. J Exp Med 1999; 189: 187-94.

[102] van Lent P, Nabbe KC, Boross P, et al. The inhibitory receptor FcgammaRII reduces joint inflammation and destruction in experimental immune complex-mediated arthritides not only by inhibition of FcgammaRI/III but also by efficient clearance and endocytosis of immune complexes. Am J Pathol 2003; 163: 1839-48.

[103] Pietersz GA, Mottram PL, van de Velde NC, et al. Inhibition of destructive autoimmune arthritis in FcgammaRIIa transgenic mice by small chemical entities. Immunol Cell Biol 2009; 87: 3-12.

[104] Abdollahi-Roodsaz S, Joosten LA, Roelofs MF, et al. Inhibition of Toll-like receptor 4 breaks the inflammatory loop in autoimmune destructive arthritis. Arthritis Rheum 2007; 56: 2957-67.
[105] Deng GM, Nilsson IM, Verdrengh M, Collins LV, Tarkowski A. Intra-articularly localized bacterial DNA containing CpG motifs induces arthritis. Nat Med 1999; 5: 702-5.

[106] Liu ZQ, Deng GM, Foster S, Tarkowski A. Staphylococcal peptidoglycans induce arthritis. Arthritis Res 2001; 3: 375-80.

[107] Zare F, Bokarewa M, Nenonen N, et al. Arthritogenic properties of double-stranded (viral) RNA. J Immunol 2004; 172: 5656-63.

[108] Solau-Gervais E, Laxenaire N, Cortet B, Dubucquoi S, Duquesnoy B, Flipo RM. Lack of efficacy of a third tumour necrosis factor alpha antagonist after failure of a soluble receptor and a monoclonal antibody. Rheumatology (Oxford) 2006; 45: 1121-4.

[109] Iannone F, Trotta F, Montecucco C, et al. Etanercept maintains the clinical benefit achieved by infliximab in patients with rheumatoid arthritis who discontinued infliximab because of side effects. Ann Rheum Dis 2007; 66: 249-52.

[110] Kremer JM, Genant HK, Moreland LW, et al. Results of a two-year followup study of patients with rheumatoid arthritis who received a combination of abatacept and methotrexate. Arthritis Rheum 2008; 58: 953-63.

[111] Genovese MC, Becker JC, Schiff M, et al. Abatacept for rheumatoid arthritis refractory to tumor necrosis factor alpha inhibition. N Engl J Med 2005; 353: 1114-23.

[112] Genovese MC, Schiff M, Luggen M, et al. Efficacy and safety of the selective co-stimulation modulator abatacept following 2 years of treatment in patients with rheumatoid arthritis and an inadequate response to anti-tumour necrosis factor therapy. Ann Rheum Dis 2008; 67: 547-54.

[113] O'Dell JR, Haire CE, Erikson N, et al. Treatment of rheumatoid arthritis with methotrexate alone, sulfasalazine and hydroxychloroquine, or a combination of all three medications. N Engl J Med 1996; 334: 1287-91.

[114] O'Dell JR, Leff R, Paulsen G, et al. Treatment of rheumatoid arthritis with methotrexate and hydroxychloroquine, methotrexate and sulfasalazine, or a combination of the three medications; results of a two-year, randomized, double-blind, placebo-controlled trial. Arthritis Rheum 2002; 46: 1164-70.

[115] Calguneri M, Pay S, Caliskaner Z, et al. Combination therapy versus monotherapy for the treatment of patients with rheumatoid arthritis. Clin Exp Rheumatol 1999; 17: 699-704.

[116] Mottonen T, Hannonen P, Leirisalo-Repo M, et al. Comparison of combination therapy with single-drug therapy in early rheumatoid arthritis; a randomised trial. FIN-RACo Trial Group. Lancet 1999; 353: 1568-73.

[117] Carmichael SJ, Beal J, Day RO, Tett SE. Combination therapy with methotrexate and hydroxychloroquine for rheumatoid arthritis increases exposure to methotrexate. J Rheumatol 2002; 29: 2077-83.

[118] Vanags D, Williams B, Johnson B, et al. Therapeutic efficacy and safety of chaperonin 10 in patients with rheumatoid arthritis; a double-blind randomised trial. Lancet 2006; 368: 855-63.

[119] Akyol S, Gercel-Taylor C, Reynolds LC, Taylor DD. HSP-10 in ovarian cancer; expression and suppression of T-cell signaling. Gynecol Oncol 2006; 101: 481-6.

[120] Capello A, Krenning EP, Breeman WA, Bernard BF, de Jong M. Peptide receptor radionuclide therapy in vitro using [111InDTPA0]octreotide. J Nucl Med 2003; 44: 98-104.

[121] Weinblatt ME, Kavanaugh A, Burgos-Vargas R, et al. Treatment of rheumatoid arthritis with a Syk kinase inhibitor; a twelve-week, randomized, placebo-controlled trial. Arthritis Rheum 2008; 58: 3309-18.

[122] Stephanie GY, Kong J, Cheema GS, Keen CL, Wick G, Gershwin ME. The immunobiology of systemic sclerosis. Semin Arthritis Rheum 2008; 38(2): 132-60.

[123] Mayes MD, Lacey JV, Jr, Beebe-Dimmer J, et al. Prevalence, incidence, survival, and disease characteristics of systemic sclerosis in a large US population. Arthritis Rheum 2003; 48: 2246-55.

[124] Mayes MD, Trojanowska M. Genetic factors in systemic sclerosis. Arthritis Res Ther 2007; 9(Suppl 2): S5.

[125] Zhou X, Tan FK, Wang N, et al. Genome-wide association study for regions of systemic sclerosis susceptibility in a Choctaw Indian population with high disease prevalence. Arthritis Rheum 2003; 48: 2585-92.

[126] Ahmed SS, Tan FK, Arnett FC. The complex genetics of scleroderma. Am J Med 2002; 112: 584-6.

[127] Genth E, Mierau R, Genetzky P, et al. Immunogenetic associations of scleroderma-related antinuclear antibodies. Arthritis Rheum 1990; 33: 657-65.

[128] Morel PA, Chang HJ, Wilson JW, et al. Severe systemic sclerosis with anti-topoisomerase I antibodies is associated with an HLADRw11 allele. Hum Immunol 1994; 40: 101-10.

[129] Rands AL, Whyte J, Cox B, Hall ND, McHugh NJ. MHC class II associations with autoantibody and $\mathrm{T}$ cell immune responses to the 
scleroderma autoantigen topoisomerase I. J Autoimmun 2000; 15 : 451-8.

[130] Dieude P, Guedj M, Wipff J, et al. Association between the IRF5 rs2004640 functional polymorphism and systemic sclerosis; a new perspective for pulmonary fibrosis. Arthritis Rheum 2009; 60: 22533.

[131] Graham RR, Kyogoku C, Sigurdsson S, et al. Three functional variants of IFN regulatory factor 5 (IRF5) define risk and protective haplotypes for human lupus. Proc Natl Acad Sci USA 2007; 104: 6758-63.

[132] Rueda B, Broen J, Simeon C, et al. The STAT4 gene influences the genetic predisposition to systemic sclerosis phenotype. Hum Mol Genet 2009; 18: 2071-7.

[133] Harvey GR, McHugh NJ. Serologic abnormalities in systemic sclerosis. Curr Opin Rheumatol 1999; 11: 495-502.

[134] Tan FK, Zhou X, Mayes MD, et al. Signatures of differentially regulated interferon gene expression and vasculotrophism in the peripheral blood cells of systemic sclerosis patients. Rheumatology (Oxford) 2006; 45: 694-702.

[135] Duan H, Fleming J, Pritchard DK, et al. Combined analysis of monocyte and lymphocyte messenger RNA expression with serum protein profiles in patients with scleroderma. Arthritis Rheum 2008; 58: 1465-74.

[136] York MR, Nagai T, Mangini AJ, Lemaire R, van Seventer JM, Lafyatis R. A macrophage marker, Siglec-1, is increased on circulating monocytes in patients with systemic sclerosis and induced by type I interferons and toll-like receptor agonists. Arthritis Rheum 2007; 56: 1010-20.

[137] Kim D, Peck A, Santer D, et al. Induction of interferon-alpha by scleroderma sera containing autoantibodies to topoisomerase I: association of higher interferon-alpha activity with lung fibrosis. Arthritis Rheum 2008; 58: 2163-73.

[138] Duncan MR, Berman B. Persistence of a reduced-collagenproducing phenotype in cultured scleroderma fibroblasts after short-term exposure to interferons. J Clin Invest 1987; 79: 1318-24.

[139] Coelho LF, de Oliveira JG, Kroon EG. Interferons and scleroderma-a new clue to understanding the pathogenesis of scleroderma? Immunol Lett 2008; 118: 110-5.

[140] Fleming JN, Nash RA, Mahoney WM, Jr, Schwartz SM. Is scleroderma a vasculopathy? Curr Rheumatol Rep 2009; 11: 10310 .

[141] Boros P, Odin JA, Chen J, Unkeless JC. Specificity and class distribution of $\mathrm{Fc}$ gamma R-specific autoantibodies in patients with autoimmune disease. J Immunol 1994; 152: 302-6.

[142] Davis K, Boros P, Keltz M, Unkeless JC, Fleischmajer R. Circulating Fc gamma receptor-specific autoantibodies in localized and systemic scleroderma. J Am Acad Dermatol 1995; 33: 612-6.

[143] Baroni SS, Santillo M, Bevilacqua F, et al. Stimulatory autoantibodies to the PDGF receptor in systemic sclerosis. N Engl J Med 2006; 354: 2667-76.

[144] Distler O, Pap T, Kowal-Bielecka O, et al. Overexpression of monocyte chemoattractant protein 1 in systemic sclerosis; role of platelet-derived growth factor and effects on monocyte chemotaxis and collagen synthesis. Arthritis Rheum 2001; 44: 2665-78.
[145] Galindo M, Santiago B, Rivero M, Rullas J, Alcami J, Pablos JL. Chemokine expression by systemic sclerosis fibroblasts; abnormal regulation of monocyte chemoattractant protein 1 expression. Arthritis Rheum 2001; 44: 1382-6.

[146] Yamamoto T, Eckes B, Hartmann K, Krieg T. Expression of monocyte chemoattractant protein-1 in the lesional skin of systemic sclerosis. J Dermatol Sci 2001; 26: 133-9.

[147] Yamamoto T, Eckes B, Krieg T. High expression and autoinduction of monocyte chemoattractant protein-1 in scleroderma fibroblasts. Eur J Immunol 2001; 31: 2936-41.

[148] Gharaee-Kermani M, McCullumsmith RE, Charo IF, Kunkel SL, Phan SH. CC-chemokine receptor 2 required for bleomycininduced pulmonary fibrosis. Cytokine 2003; 24: 266-76.

[149] Wynn TA. Cellular and molecular mechanisms of fibrosis. J Pathol 2008; 214: 199-210

[150] Ishikawa O, Ishikawa H. Macrophage infiltration in the skin of patients with systemic sclerosis. J Rheumatol 1992; 19: 1202-6.

[151] Kraling BM, Maul GG, Jimenez SA. Mononuclear cellular infiltrates in clinically involved skin from patients with systemic sclerosis of recent onset predominantly consist of monocytes/macrophages. Pathobiology 1995; 63: 48-56.

[152] van de Water J, Haapanen L, Boyd R, Abplanalp H, Gershwin ME. Identification of $\mathrm{T}$ cells in early dermal lymphocytic infiltrates in avian scleroderma. Arthritis Rheum 1989; 32: 1031-40.

[153] van de Water J, Gershwin ME, Abplanalp H, Wick G, von der Mark K. Serial observations and definition of mononuclear cell infiltrates in avian scleroderma, an inherited fibrotic disease of chickens. Arthritis Rheum 1984; 27: 807-15.

[154] Gentiletti J, McCloskey LJ, Artlett CM, Peters J, Jimenez SA, Christner PJ. Demonstration of autoimmunity in the tight skin-2 mouse; a model for scleroderma. J Immunol 2005; 175: 2418-26.

[155] Christner PJ, Peters J, Hawkins D, Siracusa LD, Jimenez SA. The tight skin 2 mouse. An animal model of scleroderma displaying cutaneous fibrosis and mononuclear cell infiltration. Arthritis Rheum 1995; 38: 1791-8.

[156] Yamamoto T. The bleomycin-induced scleroderma model; what have we learned for scleroderma pathogenesis? Arch Dermatol Res 2006; 297: 333-44.

[157] Razonable RR, Henault M, Paya CV. Stimulation of toll-like receptor 2 with bleomycin results in cellular activation and secretion of pro-inflammatory cytokines and chemokines. Toxicol Appl Pharmacol 2006; 210: 181-9.

[158] Yoshizaki A, Iwata Y, Komura K, et al. CD19 regulates skin and lung fibrosis via Toll-like receptor signaling in a model of bleomycin-induced scleroderma. Am J Pathol 2008; 172: 1650-63.

[159] Nash RA, McSweeney PA, Crofford LJ, et al. High-dose immunosuppressive therapy and autologous hematopoietic cell transplantation for severe systemic sclerosis; long-term follow-up of the US multicenter pilot study. Blood 2007; 110: 1388-96.

[160] van Laar JM, Stolk J, Tyndall A. Scleroderma lung; pathogenesis, evaluation and current therapy. Drugs 2007; 67: 985-96.

[161] Reveille JD. Genetic studies in the rheumatic diseases; present status and implications for the future. J Rheumatol Suppl 2005; 72: $10-3$

(c) Santegoets et al.; Licensee Bentham Open.

This is an open access article licensed under the terms of the Creative Commons Attribution Non-Commercial License (http://creativecommons.org/licenses/by-nc/3.0/) which permits unrestricted, non-commercial use, distribution and reproduction in any medium, provided the work is properly cited. 